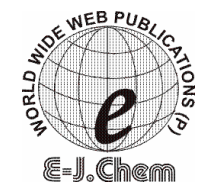

http://www.e-journals.net
ISSN: 0973-4945; CODEN ECJHAO

E-Journal of Chemistry

Vol. 5, No. 1, pp. 163-168, January 2008

\title{
Microwave Enhanced Synthesis of Flax-g-poly(MMA) for Use in Phenolic Composites as Reinforcement
}

\author{
SUSHEEL KALIA*, B. S. KAITH \\ *Department of Chemistry, Singhania University, Pacheri Badi, Jhunjhunu - 333515 India \\ Department of Chemistry, NIT (Deemed University), Jalandhar - 144011 India \\ susheel_kalia@yahoo.com
}

Received 7 September 2007; Accepted 20 October 2007

\begin{abstract}
Graft copolymerization of methyl methacrylate (MMA) onto flax fiber under the influence of microwave radiations (MWR) was carried out. $24.64 \%$ grafting was found at $210 \mathrm{~W}$ microwave power under optimum reaction conditions. The graft copolymers were characterized with FTIR spectroscopy, scanning electron microscopy (SEM) and X-ray diffraction (XRD) techniques. Graft copolymers thus prepared were used in the preparation of phenol-formaldehyde (PF) composites. Modulus of rupture (MOR), modulus of elasticity (MOE) and stress at the limit of proportionality (SP) of composites were measured and it has been found that composites reinforced with Flax-g-poly(MMA) showed better mechanical properties in comparison to composites reinforced with raw flax.
\end{abstract}

Keywords: Flax, Grafting, MWR, Composites and mechanical behaviour

\section{Introduction}

Alfrey and Bandel ${ }^{1}$ were the first to synthesize graft copolymers in 1950 . They polymerized vinyl acetate in presence of Styrene and vinylidene chloride. The concept of graft copolymer was actively promoted by Mark H.F. ${ }^{2}$ announcing new graft copolymers and the area of graft copolymerization research was thoroughly renewed. During 1960's the research on grafting remained active. In early 1970's graft copolymerization and its potential was reviewed in several books ${ }^{3}$. Grafting involves attachment of polymer chains, usually synthetic, to the back-bone polymer. It is one of the methods to increase the compatibility between synthetic polymers and cellulose ${ }^{4}$. The process of grafting has been explained by Schwab et $a l^{5}$. Modification of fibrous proteins and cellulose through graft copolymerization has been reported by Chauhan et al ${ }^{6}$. 
Composites reinforced with cellulosic fibers have received considerable interest in recent years. The advantages of natural fibers reinforced composites over traditional material reinforced composites are biodegradability ${ }^{7}$, better mechanical properties and low density ${ }^{8}$. Fiber reinforced composites offer numerous technical advantages for engineering, automobiles and other industrial applications. These composites are used in different fields ranging from the material with relatively low mechanical properties for elementary purposes to the material with high performance ${ }^{9,10}$. Kaith et al ${ }^{11-12}$ have reported the reinforcement of polystyrene composites with graft copolymers of flax fiber. Canche-Escamilla et al ${ }^{13}$ have studied the mechanical properties of acrylate grafted henequen cellulose fibers and their applications in composites and found that best results obtained with poly(MMA) grafted cellulose fibers because of the better fiber-matrix adhesion.

MWR technique reduces the extent of physico-chemical stresses to which the fibers are exposed during the conventional techniques ${ }^{14}$. It has been reported that properties of fibers treated under MWR assisted technique are same or even better than those of fibers modified through other conventional techniques ${ }^{15,16}$. Polyacrylamide was graft copolymerized onto chitosan and guar gum using MWR and maximum grafting of $169 \%$ and $66.66 \%$ was observed in 1.16 and 0.22 minutes, respectively under optimum reaction conditions ${ }^{17,18}$. Since grafting under MWR is advantageous in terms of time consumption and cost effectiveness, so attempts have been made to graft copolymerized MMA onto flax fiber under the influence of MWR. Graft copolymers thus prepared are used as reinforcement in the preparation of phenol-formaldehyde (PF) composites.

Since the use of Flax-g-copolymers as reinforcement for plastics is meagerly reported in literature, therefore, in the present paper, reinforcement of phenol-formaldehyde matrix with Flax-g-poly(MMA) and the evaluation of their different mechanical studies have been reported.

\section{Experimental}

Flax fiber (Linum usitatissimum) was obtained from the Department of Agronomy, CSK HP Agriculture University, Palampur (India). Phenol ( $\mathrm{S} d$ fine-chem ltd., India) and formaldehyde ( $\mathrm{CDH}$, India) were used as received. Monomers were washed with 5\% sodium hydroxide followed by water and were dried over anhydrous sodium sulphate. The dried monomers were distilled and the middle fraction was used. Composites were prepared in Compression Molding Machine (SANTEC India Ltd.). Libror AEG-220 (Shimadzu make) electronic balance was used for weighing purpose.

FTIR spectra of the samples were recorded with $\mathrm{KBr}$ pellets on Perkin Elmer RXI Spectrophotometer. Scanning electron microscopic analysis of the flax and its graft copolymers were carried-out on Electron Microscopy Machine (LEO 435VP). X-ray diffraction studies were carried out on Bruker- $\mathrm{D}_{8}$ advance model X-ray diffractometer using Segal formula ${ }^{19}$.

Strength of fibers was measured with Stelometer (MAG, FO501). Mechanical properties of composites were carried out on Universal Testing Machine (HOUNSFIELD, H25KS).

\section{Graft copolymerization of binary vinyl monomer mixtures onto flax fibers}

Flax fiber $(0.5 \mathrm{gm})$ was immersed in $100 \mathrm{~mL}$ of distilled water for 24 hours prior to their grafting under the influence of MWR. Known amount of monomer [MMA (x 10-3 mol/L) = 1.96] and definite ratio of FAS- $\mathrm{H}_{2} \mathrm{O}_{2}(1: 6)$ were added to the reaction mixture. The reaction mixture was stirred and transferred to microwave reactor at $210 \mathrm{~W}$ microwave power for a definite time interval (30 minutes). Various reaction parameters were optimized and the separation of homo-polymer from the grafted fibers was carried-out so as to get maximum 
graft yield. Graft copolymers obtained were dried in hot air oven at $50{ }^{\circ} \mathrm{C}$ till constant weight was obtained. The percentage grafting $\left(\mathrm{P}_{\mathrm{g}}\right)$ was calculated as follows:

$$
\mathrm{P}_{\mathrm{g}}=\frac{\mathrm{W}_{2}-\mathrm{W}_{1}}{\mathrm{~W}_{1}} \times 100
$$

Where $\mathrm{W}_{1}$ and $\mathrm{W}_{2}$ are the weights of flax fibers and grafted flax fibers, respectively.

\section{Fiber strength of graft copolymers}

Fiber strength was measured with fiber bundle strength tester (Stelometer) using standard test method ASTM D-1445-95 (Flat Bundle Method). Known weight of fiber bundle was put in Stelometer and the total strength (gms/tex) required to break the fibers was measured and calculated as follows:

$$
\text { Strength }(\mathrm{Kg} / \mathrm{mg})=\frac{\text { Total strength of fibers in } \mathrm{Kg}}{\text { Total weight of fibers in } \mathrm{mg}}
$$

Strength $($ gms/tex $)=$ Strength $(\mathrm{Kg} / \mathrm{mg}) \times 15.0$ (constant factor $)$

Actual Strength $(\mathrm{gms} / \mathrm{tex})=$ Strength $(\mathrm{gms} / \mathrm{tex}) \mathrm{x}$ Humidity correction factor

Whereas, Humidity correction factor at RH $53 \%$ is 1.0756

\section{Preparation of composites}

Phenol-formaldehyde resin was thoroughly mixed with fibers (10:0.5 w/w). After thorough mixing of the resin and fibers, the mixture was poured in molds. The surfaces of molds were coated on the inside with oleic acid to avoid adhesion of the mixture and to allow easy removal of the composites. The whole assembly was then placed inside the hot press and cured at $90{ }^{\circ} \mathrm{C}$ and a pressure of $10 \mathrm{Kg} / \mathrm{cm}^{2}$ for $5 \mathrm{~h}$. Composites thus prepared were subjected for the evaluation of different mechanical properties. The numbers of specimen used for the determination of mechanical properties were three and the tests were conducted at ambient laboratory conditions.

Modulus of rupture, modulus of elasticity and stress at the limit of proportionality

MOR, MOE and SP were determined according to ASTM D 790 in a universal testing machine and were calculated by using the following equations:

$$
\begin{aligned}
\mathrm{MOR} & =\frac{3 \mathrm{PL}}{2 \mathrm{bd}^{2}} \mathrm{~N} / \mathrm{mm}^{2} \\
\mathrm{MOE} & =\frac{\mathrm{P}_{1} \mathrm{~L}^{3}}{4 \mathrm{bd}^{3} \mathrm{y}} \mathrm{N} / \mathrm{mm}^{2} \\
\mathrm{SP} & =\frac{3 \mathrm{P}_{1} \mathrm{~L}}{2 \mathrm{bd}^{2}} \mathrm{~N} / \mathrm{mm}^{2}
\end{aligned}
$$

Where $\mathrm{P}=$ peak load, $\mathrm{P}_{1}=$ load at the limit of proportionality, $\mathrm{L}=$ length of sample, $\mathrm{b}=$ width of the sample, $\mathrm{d}=$ thickness of the sample and $\mathrm{y}=$ rate of bending.

\section{Results and Discussion}

\section{Optimized reaction parameters}

Optimum reaction conditions for getting maximum graft yield were: MMA $\left(1.96 \times 10^{-3} \mathrm{~mol} \mathrm{~L}^{-1}\right)$; FAS- $\mathrm{H}_{2} \mathrm{O}_{2}$ (molar ratio), 1:6; time (min.), 30 and pH, 7.0. 


\section{Characterization of graft copolymers}

\section{FTIR Spectroscopy}

Flax fiber showed broad peaks at $3422.8 \mathrm{~cm}^{-1}$ due to bonded $-\mathrm{OH}$ and at 2918.8, 1653.5 and $1058.7 \mathrm{~cm}^{-1}$ arising from $-\mathrm{CH}_{2}, \mathrm{C}-\mathrm{C}$ and $\mathrm{C}-\mathrm{O}$ stretching, respectively. However, in case of Flax-g-poly(MMA)-MWR an additional peak at $1731.2 \mathrm{~cm}^{-1}$ has been observed due to $>\mathrm{C}=\mathrm{O}$ group of MMA. This suggests that PMMA has been grafted onto flax through covalent linkages.

\section{Scanning Electron Microscopy}

The scans could easily verify the fact that cellulosic fibers lying apart in original sample started forming bundles in the graft copolymers. A clear cut distinction between scanning electron micrographs of original flax and its graft copolymer, Flax-g-poly(MMA) has been observed (Figs. 1-2).

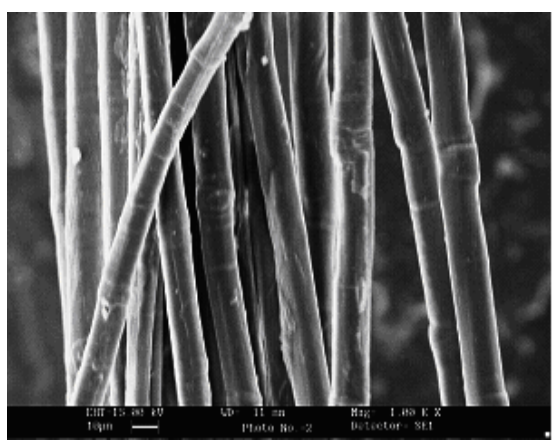

Figure 1. SEM of flax fiber

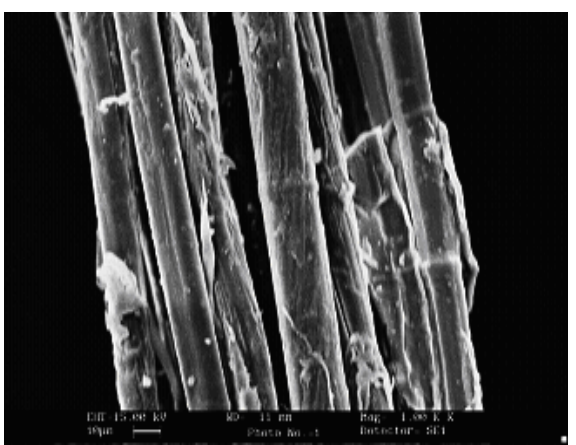

Figure 2. SEM of Flax-g-poly(MMA)

\section{X-Ray Diffraction Studies}

It is evident from Table 1 that flax fiber and Flax-g-poly(MMA)-MWR showed 76.96 and 68.98 percentage crystallinity (\% Cr), respectively. Crystallinity index (C.I.) of flax fiber and Flax-g-poly(MMA)-MWR has been observed to be 0.7005 and 0.5502 , respectively.

Table 1. Percentage crystallinity (\%Cr) and crystallinity index (C.I.) of flax fiber and Flaxg-poly(MMA)

\begin{tabular}{ccccccc}
\hline \multirow{2}{*}{ S. No. } & \multirow{2}{*}{ Sample } & \multirow{2}{*}{$\mathrm{P}_{\mathrm{g}}$} & \multicolumn{2}{c}{ at $2 \theta$ scale } & \multirow{2}{*}{ Cr, } & \multirow{2}{*}{ C.I. } \\
\cline { 4 - 5 } & & - & $\mathrm{I}_{22}$ & $\mathrm{I}_{18}$ & $\%$ & \\
\hline 1. & Flax fiber & & 1780 & 533 & 76.96 & 0.7005 \\
2. & Flax-g-poly(MMA) & 24.64 & 2466 & 1109 & 68.98 & 0.5502 \\
\hline
\end{tabular}

The X-ray diffraction spectra of flax fiber and graft copolymer were analyzed and it has been found that the spectrum of flax fiber is more convex than that of graft copolymers. In case of flax fiber, the incorporation of poly(MMA) chains to the back-bone of the flax backbone had impaired the crystallinity of flax fiber. Therefore, on grafting $\% \mathrm{Cr}$ decreases rapidly with reduction in its stiffness and hardness. C.I. gives a quantitative measure of the orientation of the cellulose crystals in fibers. X-ray diffraction patterns are visual indicators of the orientation of the cellulose crystals. The intensity, size, and shape of the diffracting arcs in a fiber diffraction pattern are determined by the size and orientation of the cellulose crystals in the fibers. The diffraction of flax fiber produces narrow and bright patterns that are characteristic of oriented crystals. On the other hand, the diffraction pictures of 
Flax-g-poly(MMA) showed long diffracting arcs that end sharply. This is due to misorientation of the cellulose crystals to the fiber axis during grafting as indicated by the lower crystallinity index in Flax-g-poly(MMA)-MWR . The diffraction patterns of flax fiber showed bright and narrow equatorial reflections. This clearly indicates that the cellulose crystals are better oriented in flax fiber in comparison to Flax-g-poly(MMA)-MWR.

\section{Fiber Strength}

It has been observed that there is increase in fiber strength on grafting of flax with MMA. This is due to the fact that optimum reaction time for getting maximum graft yield is quite less, so grafting has resulted in less surface flaws and the crystal lattice of the fiber is not disturbed very much which leads to increase in fiber strength (Table 2).

Table 2. Effect of percent grafting on fiber strength

\begin{tabular}{ccc}
\hline Sample Code & \% Grafting & $\begin{array}{c}\text { Fiber Strength, } \\
\text { gms/tex }\end{array}$ \\
\hline Flax fiber & - & 28.84 \\
Flax-g-poly(MMA) & 24.64 & 46.96 \\
\hline
\end{tabular}

\section{Modulus of Rupture, Modulus of Elasticity and Stress at the limit of Proportionality}

It is evident from Table 3 that PF Composites reinforced with graft copolymers prepared under the influence of microwave radiations showed the maximum values of MOR, MOE and SP. Maximum value of MOR, MOE and SP were found to be 72.0, 3490.56 and 65.45 $\mathrm{N} / \mathrm{mm}^{2}$ for the composites reinforced with Flax-g-poly(MMA).

Table 3. MOR, MOE and SP values of PF and composites reinforced with Flax-gpoly(MMA)

\begin{tabular}{cccc}
\hline Sample & $\begin{array}{c}\text { MOR, } \\
\text { N/mm }\end{array}$ & $\begin{array}{c}\text { MOE, } \\
\mathrm{N} / \mathrm{mm}^{2}\end{array}$ & $\begin{array}{c}\text { SP, } \\
\mathrm{N} / \mathrm{mm}^{2}\end{array}$ \\
\hline Phenol-Formaldehyde & 36.0 & 1336.32 & 25.06 \\
Flax fiber Reinforcement & 72.0 & 3280.64 & 61.51 \\
Flax-g-poly(MMA) Reinforcement & 72.0 & 3490.56 & 65.45 \\
\hline
\end{tabular}

Results showed that reinforcement of Flax-g-poly(MMA) increased the MOR, MOE and SP in comparison to flax. This is due to reason that graft copolymers prepared under the influence of MWR resulted in lesser surface flaws. Moreover, the optimum reaction time (30 minutes) for getting maximum grafting under the influence of MWR is very less. This has resulted in less surface flaws and hence fewer disturbances in the crystal lattice of the fiber thereby resulting in better mechanical strength. Moreover, the fiber strength of graft copolymers prepared under the influence of MWR was found much more than that of flax.

\section{Conclusion}

Microwave radiation induced grafting is an effective method for modifying the properties of natural fibers in terms of time consumption and cost effectiveness. Crystalline structure of flax was not disturbed very much and fiber strength of flax fibers has been found to increase on grafting with MMA. Composites reinforced with Flax-g-poly(MMA) showed better mechanical properties in comparison to flax fibers reinforcement.

\section{References}

1. Alfrey T and Bandel D, Paper presented at $118^{\text {th }}$ Am. Chem. Soc. Meeting, Chicago, Sep. 4, 1950, through Mark H F, Rec. Chem. Progr., 12, 139, 1951. 
2. Mark H F, Text. Res. J., 1953, 23, 294-298.

3. Battaerd H A J and Tregear G W, Ed., 'Graft Copolymers' Interscience, New York, 1967.

4. Hebeish A and Guthrie J T, The chemistry and Technology of Cellulosic Copolymers. Heidelberg: Springer Verlag, 1981.

5. Schwab E, Stannett V and Hermans J J, TAPPI., 1961 44, 251-256.

6. Chauhan G S, Guleria L K, Misra B N and Kaur I, J. Polym. Sci. Part A: Polym. Chem., 1999, 37,1763-1769.

7. Simon J, Müller H P, Koch R and Müller V, Polym. Degrad. Stab., 1998, 59:107-115.

8. Joly C, Kofman M and Gauthier R, J. Macromol. Sci. Pure Appl. Chem., 1996, 33:1981-1996.

9. Augl J M and Berger A E, Moisture effect on carbon epoxy composites. Proceedings of the $8^{\text {th }}$ national SAMPE technical conference, SAMPE, Covina, Seattle, WA, pp. 386-427, 1976.

10. King J, Chaudhary $M$ and Zahir S, $20^{\text {th }}$ National SAMPE Symp., SAMPE, Covina, CA, pp. 392, 1984.

11. Kaith B S, Singha A S, Dwivedi D K, Kumar S, Kumar D. and Dhemeniya A, Int. J. Plast. Tech., 2003, 7, 119-125.

12. Dwivedi D K, Singha A S, Kumar S and Kaith B S, Int. J. Plast. Tech., 2004, 8, 299-304.

13. Canche'-Escamilla G, Cauich-Cupul J I, Mendiza'bal E, Puig J E, Va'zquez-Torres H and Herrera-Franco P J, Composites: Part A, 1999, 30, 349-359.

14. Tsukada M, Islam S, Arai T, Boschi A and Freddi G, Autex Res. J., 2005, 5, 40-48.

15. Freddi G, Massafra M R, Beretta S, Shibata S, Gotoh Y, Yasui H and Tsukada M, J. Appl. Polym. Sci., 1996, 60, 1867-1876.

16. Tsukada M, Islam S, Arai T, Boschi A and Freddi G, Int. Nonwovens J., 2001, 10, 4.

17. Singh V, Tiwari A, Tripathi D N and Sanghi R, Carbohydrate Polymers, 2004, 58, 1-6.

18. Singh V, Tiwari A, Tripathi D N and Sanghi R, Polymer, 2006, 47, 254-260.

19. Segal L C, Martin A E and Conrad C M, Textile Res. J., 1959, 29, 786-794. 


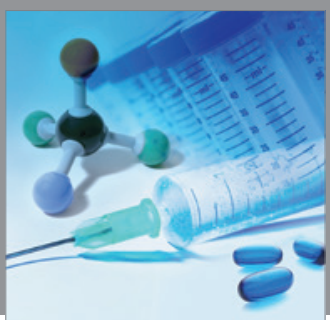

International Journal of

Medicinal Chemistry

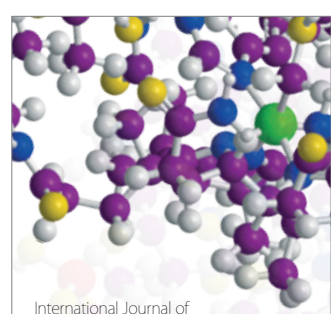

Carbohydrate Chemistry

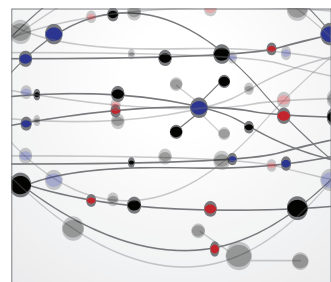

The Scientific World Journal
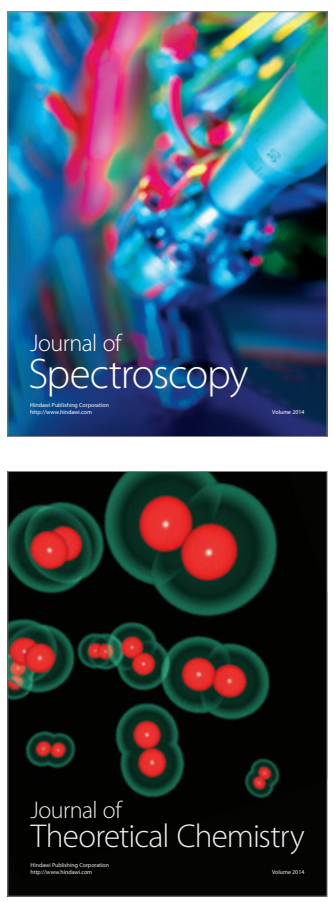
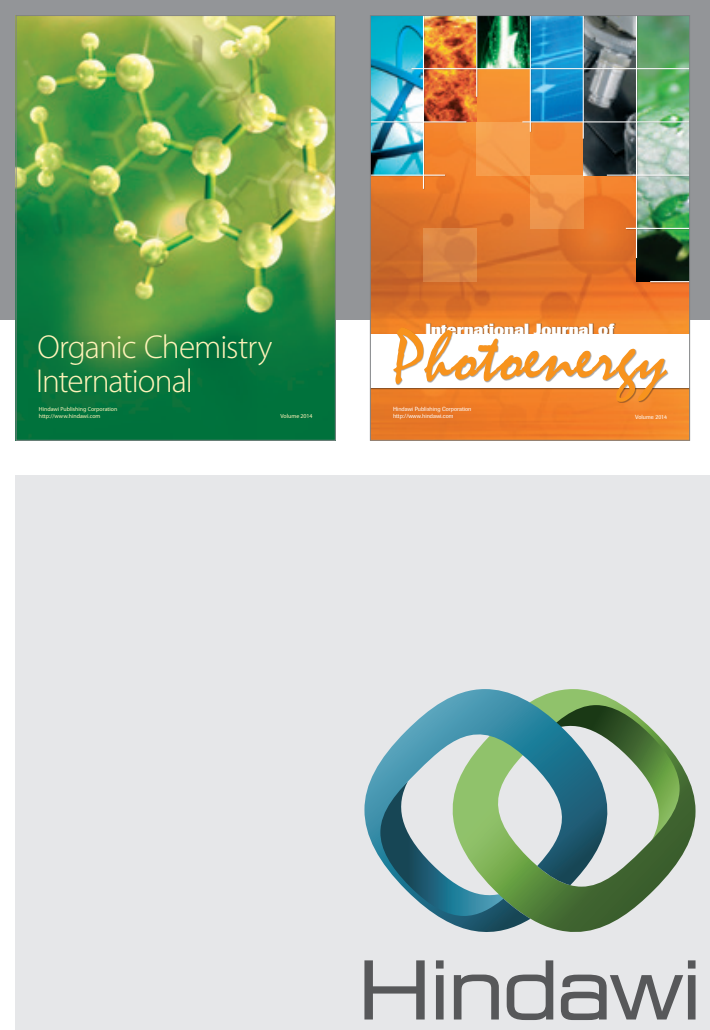

Submit your manuscripts at

http://www.hindawi.com
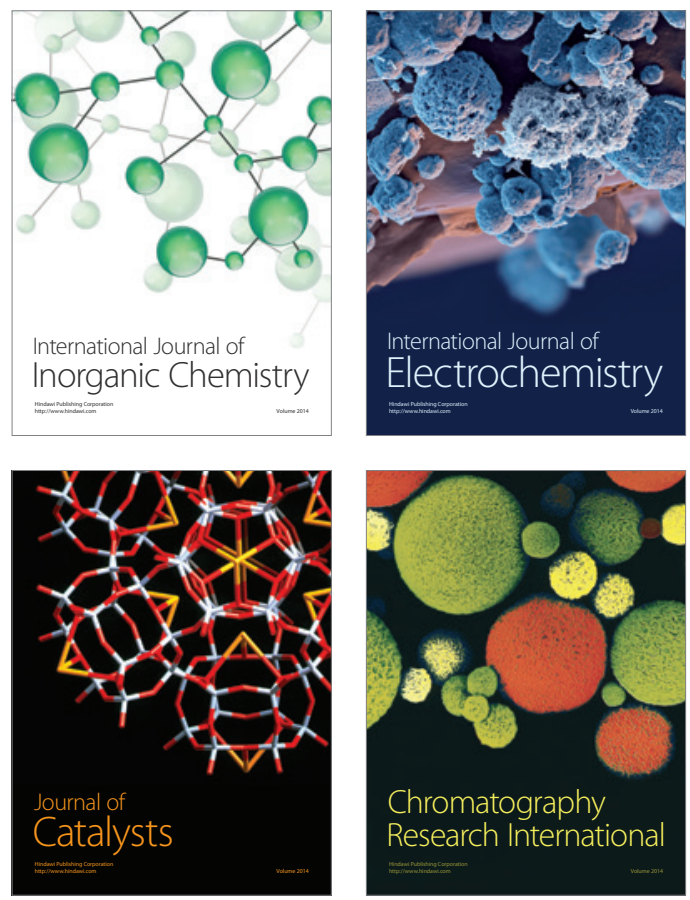
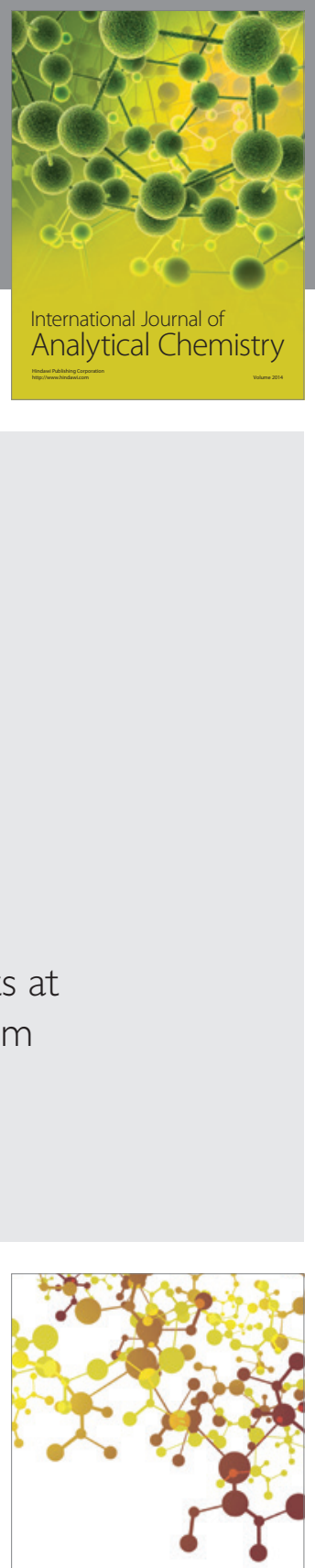

Journal of

Applied Chemistry
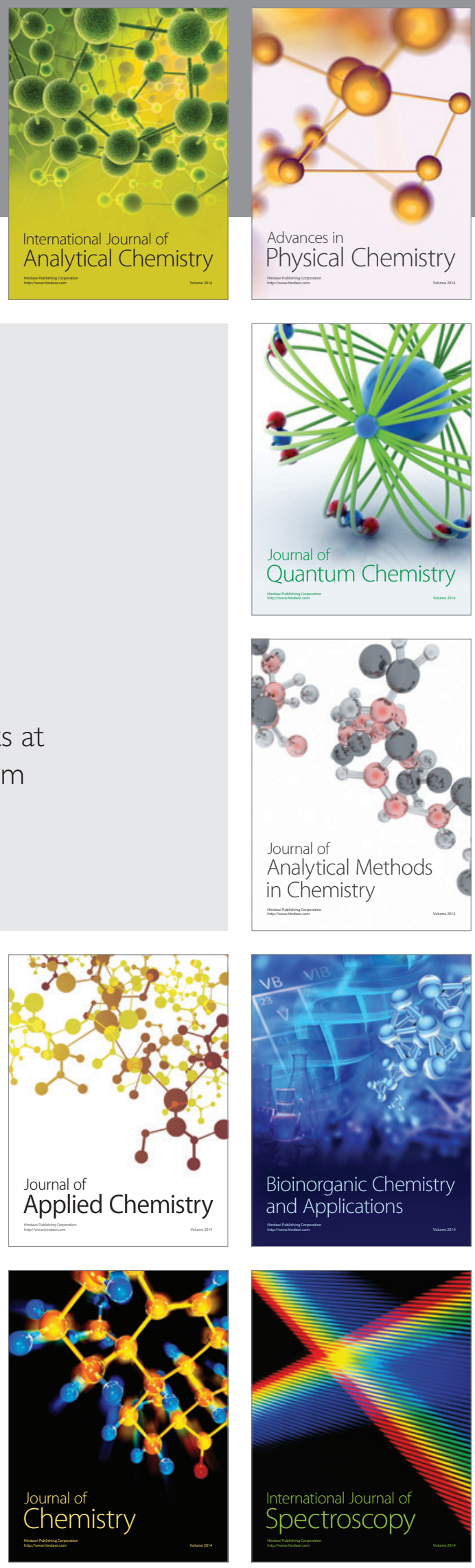